\title{
Is Anti-platelet Treatment Necessary for Penile Mondor's Disease?
}

\section{Penil Mondor Hastalı̆̆ında Anti-platelet Tedavi Gerekli midir?}

\author{
(D) Ahmet Murat Bayraktar, (D) Muhammet İrfan Dönmez \\ Konya Training and Research Hospital, Clinic of Urology, Konya, Turkiye
}

\section{What's known on the subject? and What does the study add?}

Literature regading treatment of penile Mondor's disease (thrombophlebitis of dorsal penile vein) is heterogeneous. Therefore, treatment is not standardized. With this study, we showed there is no need for anti-platelet treatment for penile Mondor's disease as thrombus resolution rates did not differ in antibiotic vs antibiotic + anti-platelet groups.

\section{Abstract}

Objective: The aim of this study was to determine if anti-platelet treatment would have any effect on the rate and duration of resolution in penile Mondor's disease.

Materials and Methods: A retrospective review of patients diagnosed with Mondor's disease between 2014 and 2018 was conducted. The patients were divided into two groups with regard to anti-platelet treatment. Age, initial symptom, medications [short-term fluoroquinolone antibiotics (Ab) \pm low-dose acetyl salicylic acid (ASA)], and erectile function scores were evaluated. Moreover, ultrasonographic findings (location and length of thrombus) were noted.

Results: A total of 14 patients were diagnosed with penile Mondor's disease. The mean age of the patients was 36 years (range: 18-66). The initial symptom was penile induration in all patients. Thrombus was located distally in 3 , mid penile in 5 and proximally in 6 . The median length of thrombus was $20 \mathrm{~mm}$ (range: 10-50 mm). In 13 patients (92.8\%), thrombus resolved and patients became symptom-free. The median time to resolution was 3 weeks (range: 2-7). Eight patients received Ab + ASA while 5 received Ab only. There was no statistically significant difference between the groups in terms of the rate and duration of resolution ( $p=1.00$ and 0.55 , respectively).

Conclusion: Our results showed that anti-platelet treatment may be unnecessary for the treatment of penile Mondor's disease.

Keywords: Penile, Mondor's disease, Anti-platelet, Treatment

$\ddot{0 z z}$

Amaç: Çalışmamızın amacı anti-platelet tedavinin penil Mondor hastalığında rezolüsyon oranına ve rezolüsyon süresine olan etkisini araştırmaktır. Gereç ve Yöntem: Kliniğimizde 2014-2018 yılları arasında penil Mondor hastalığı tanısı almış hastaların dosyaları geriye dönük olarak tarandı. Hastalar anti-platelet tedavi alıp almamalarına göre iki gruba ayrıldı. Yaş, başvuru şikayeti, verilen tedavi [kısa süreli florokinolon antibiyotikler (Ab) \pm düşük doz asetil salisilik asit (ASA)] ve erektil fonksiyon skorlarına ait bilgiler kaydedildi. Ek olarak, ultrasonografi bulguları (trombüs uzunluğu ve yerleşimi) not edildi.

Bulgular: Toplamda penil Mondor hastalığı tanısı almış 14 hasta çalışmaya dahil edildi. Hastaların ortalama yaşları 36 (18-66 aralığında) olarak bulundu. Tüm hastalarda başvuru şikayeti peniste şişlik olarak saptandı. Trombüs, 3 hastada distalde, 5 hastada mid penil ve 6 hastada proksimal yerleşimdeydi. Medyan trombüs boyutu $20 \mathrm{~mm}$ (10-50 mm aralığında) idi. Trombüs toplamda 13 hastada (\%92,8) rezolüsyona uğradı ve hastaların şikayetleri tamamen geriledi. Medyan rezolüsyon süresi 3 hafta (2-7 hafta arası) olarak bulundu. Çalışmamızda, 8 hasta Ab + ASA tedavisi almış iken 5 hastanın yalnızca Ab tedavisi almış olduğu saptandı. İki grup arasında rezolüsyon oranı ve rezolüsyon süresi arasında istatistiksel anlamlı fark bulunmadı (sırasıyla, $p=1,00$ ve 0,55 ).

Sonuç: Çalışmamızın sonuçlarına göre penil Mondor hastalığının tedavisinde anti-platelet tedavi gereksiz olabilir.

Anahtar Kelimeler: Penis, Mondor hastalığı, Anti-platelet, Tedavi

Correspondence: Muhammmet İrfan Dönmez MD, Konya Training and Research Hospital, Clinic of Urology, Konya, Turkiye

E-mail: m_irfan83@yahoo.com ORCID-ID: orcid.org/0000-0002-2828-7942

Received: 17.10.2018 Accepted: 27.10.2018

Cite this article as: Bayraktar AM, Dönmez Mi. Is Anti-platelet Treatment Necessary for Penile Mondor's Disease? J Urol Surg 2019;6(1):42-45.

${ }^{\circ}$ Copyright 2019 by the Association of Urological Surgery / Journal of Urological Surgery published by Galenos Publishing House. 


\section{Introduction}

Named after French surgeon Henri Mondor, Mondor's disease (MD) has been described in late 1930s as thrombophlebitis of the superficial veins of the chest wall (1). However, thrombophlebitis of any location of the body can be called as MD. On the other hand, penile MD, described two decades later, is the thrombophlebitis of the superficial dorsal penile veins (2). It is relatively rare, benign, and usually self-limiting with possible spontaneous resolution. Literature regarding penile MD is limited due to a huge number of case reports but no larger scale series.

Although the exact cause is unknown, some conditions that might lead to MD have been postulated. These include a hypercoagulative state, vasculitis, cancer and sexuallytransmitted diseases (3). Additionally, lymphangitis as the underlying pathology has also been reported (4). The common etiologic factor for penile MD has been proposed to be trauma (vigorous/prolonged sexual intercourse, masturbation, etc.) (5). The main complaint of the patients with penile MD is induration on the back of the penis with or without pain (6).

As penile MD is usually self-limiting and tends to resolve spontaneously, the treatment for the disease has been conservative in cases when there is no underlying cause. However, non-steroidal anti-inflammatory medication, anticoagulant ointment and antibiotic (Ab) prescription may be suitable for those with prominent inflammation (3). Eventually, data regarding any drugs that would change the course of the disease is scarce. The aim of this study was to evaluate if anti-platelet treatment would have any effect on the rate and duration of resolution in penile MD.

\section{Materials and Methods}

After obtaining approval from the local ethics committee (Konya Training and Research Hospital, number: 06.09.2018:17-02), a retrospective review of patients diagnosed with MD between 2015 and 2018 was conducted. Due to retrospective nature of the study informed consents were not obtained. Age, initial symptom, medications, and erectile function scores (IIEF-5) were evaluated. The patients received either a short course treatment with fluoroquinolone $\mathrm{Ab}$ (500 mg twice daily for 5 days) alone or with a combination of $A b$ and low-dose anti-platelet [acetyl salicylic acid (ASA) 1×100 mg daily] until resolution of thrombus. The patients were divided into two groups with regard to anti-platelet treatment status. All patients underwent Doppler ultrasonography (US) for confirmation of the diagnosis. Moreover, ultrasonographic findings (location and length of thrombus) were noted. The patients were followed up weekly and those with no sign of induration during the follow-up were regarded as having complete resolution. Time to resolution (weeks) and resolution rates were determined.

\section{Statistical Analysis}

The GraphPad Prism software was used for statistical analysis. Continuous variables were analyzed using Student's t-test where categorical variables were analyzed using Fischer's exact test. A $p$ value of less than 0.05 was considered statistically significant.

\section{Results}

A total of 14 patients were diagnosed with penile MD. The mean age of the patients was 36 years (range: 18-66). The initial symptom was penile induration in all patients. Doppler US results showed that thrombus was located in the distal penile shaft in 3 , in the mid-shaft in 5 and, in the proximal shaft in 6. The median length of thrombus was $20 \mathrm{~mm}$ (range: 10-50 mm). In 13 patients $(92.8 \%)$, thrombus resolved and patients became symptom-free. A 66-year-old patient in Ab + ASA group did not show resolution after 9 weeks and has been lost to follow-up. The median time to resolution was 3 weeks (range: 2-7 weeks). In our study, nine patients received $A b+$ ASA while 5 received Ab only. There was no statistically significant difference between the groups in terms of the rate and duration of resolution ( $p=1.00$ and $p=0.55$, respectively). Median IIEF- 5 scores of both groups were comparable (23.5 vs $24, p=0.45)$. There were two patients with co-morbidities in the $\mathrm{Ab}+\mathrm{ASA}$ and none in Ab only groups. One of them had asthma and the other had hypertension that was controlled by a single calcium channel blocker. None of the patients had a history of thrombophilia. Table 1 summarizes data of the patients.

\section{Discussion}

Penile MD is actually not an infrequent disease with a prevalence of $1.4 \%$ (7). The main complaints of the patients are penile induration and pain (8). However, it is a relatively under-diagnosed problem, possibly due to a self-limiting and benign course as well as lack of severe symptoms. Therefore, there are no large-scale studies on penile MD and its treatment. Although it has a high resolution rate, patients' anxiety is an important aspect of the disease that drives physicians to prescribe medications. As penile MD is a thrombophlebitis, the main goal of the treatment is to reduce inflammation and resolve thrombosis. Physicians tend to prescribe different types of medications such as antibiotics, anti-platelet agents, non-steroidal anti-inflammatory drugs, and topical heparinoid ointments (3). It has been reported that antibiotic use might be beneficial especially in patients with acute cellulitis (9). Second generation cephalosporins and Abs have been suggested, possibly due to their Gram-negative bacteria coverage (3). All 
Table 1. Overview of patients

\begin{tabular}{|c|c|c|c|c|c|c|}
\hline Patient number & Age & $\begin{array}{l}\text { Location of } \\
\text { thrombus }\end{array}$ & $\begin{array}{l}\text { Length of } \\
\text { thrombus (mm) }\end{array}$ & Co-morbidity & Treatment & $\begin{array}{l}\text { Time to resolution } \\
\text { (weeks) }\end{array}$ \\
\hline$\# 1$ & 18 & Proximal & 20 & None & $A b$ & 3 \\
\hline \#2 & 31 & Proximal & 20 & None & $A b$ & 3 \\
\hline \#3 & 58 & Proximal & 20 & None & $\mathrm{Ab}$ & 4 \\
\hline$\# 4$ & 29 & Mid penile & 15 & None & $\mathrm{Ab}$ & 3 \\
\hline$\# 5$ & 35 & Proximal & 15 & None & $\mathrm{Ab}$ & 3 \\
\hline \#6 & 33 & Mid penile & 25 & None & $A b+A S A$ & 4 \\
\hline$\# 7$ & 23 & Mid penile & 30 & None & $A b+A S A$ & 7 \\
\hline \#8 & 29 & Distal & 10 & None & $A b+A S A$ & 2 \\
\hline \#9 & 30 & Proximal & 25 & Asthma & $A b+A S A$ & 4 \\
\hline$\# 10$ & 66 & Proximal & 50 & None & $A b+A S A$ & - \\
\hline \# 11 & 53 & Distal & 20 & HT & $A b+A S A$ & 3 \\
\hline$\# 12$ & 38 & Distal & 20 & None & $A b+A S A$ & 4 \\
\hline$\# 13$ & 32 & Mid penile & 15 & None & $A b+A S A$ & 2 \\
\hline \#14 & 20 & Mid penile & 10 & None & $A b+A S A$ & 2 \\
\hline
\end{tabular}

Ab: Antibiotic, ASA: Acetyl salicylic acid, HT: Hypertension

patients were admitted in the acute phase of the disease and thus, a 5-day Ab regimen was used. There is no study to date that evaluates and/or compares treatment options in penile MD.

In our study, we compared two groups of patients with regard to medical treatment. One group of patients received shortcourse Ab only and the other received Ab and low-dose ASA. There were no statistically significant differences between the groups in terms of rate of resolution and time to resolution. Even though the sample size was small and the side effects of low-dose ASA is scarce, our findings may contribute to reducing overtreatment of penile MD.

The most common etiology is trauma (prolonged sexual intercourse). On the other hand, infections, inflammatory processes, recent surgery for adjacent tissues and cancer may lead to penile MD (10). It is necessary to determine the etiology and treat the patient accordingly. There were no cases in our cohort that were secondary to previously stated conditions, so our data most likely represents a population of patients developing penile MD due to trauma to the penis.

Penile Doppler US is also found to be a good tool to evaluate these patients (11). Magnetic resonance angiography has been also shown to help diagnose penile MD (12), however, in our study, all patients were easily diagnosed using Doppler US in addition to physical examination. Doppler US is also important to make a differential diagnosis between sclerosing lymphangitis of the penis and Peyronie's disease (7).

In their study, Ozkan et al. (3) showed that MD was not associated with erectile dysfunction or permanent deformation of the penis. Our study was not designed to address this issue, but our findings include a normal IIEF- 5 score in both groups before treatment. As most of our patients showed resolution of the thrombus and symptoms, it would not be naive to expect them to have no erectile dysfunction afterwards.

\section{Study Limitations}

Limitations of our study include retrospective design, lack of a control group, and small sample size. On the other hand, it is one of the few studies comparing two different treatments.

\section{Conclusion}

Our results showed that anti-platelet treatment may be unnecessary for the treatment of penile MD.

\section{Ethics}

Ethics Committee Approval: The approval was taken from the local ethics committee (Konya Training and Research Hospital, number: 06.09.2018:17-02).

Informed Consent: Retrospective study.

Peer-review: Internally peer-reviewed.

\section{Authorship Contributions}

Concept: A.M.B., M.I.D., Design: A.M.B., M.I.D., Data Collection or Processing: A.M.B., M.I.D., Analysis or Interpretation: A.M.B., M.I.D., Literature Search: A.M.B., M.I.D., Writing: A.M.B., M.I.D.

Conflict of Interest: No conflict of interest was declared by the authors. 
Financial Disclosure: The authors declared that this study received no financial support.

\section{References}

1. Amano M, Shimizu T. Mondor's Disease: A Review of the Literature. Intern Med 2018.

2. Ozturk H. Penile Mondor's disease. Basic Clin Androl 2014;24:5.

3. Ozkan B, Coskuner ER, Turk A, Akkus E, Yalcin V. Penile Mondor disease and its effect on erectile function: results of 30 patients. Urology 2015;85:113117.

4. Ichinose A, Fukunaga A, Terashi $H$, Nishigori $C$, Tanemura A, Nakajima $T$, Akishima-Fukasawa $Y$, Ishikawa $Y$, Ishii T. Objective recognition of vascular lesions in Mondor's disease by immunohistochemistry. J Eur Acad Dermatol Venereol 2008;22:168-173.

5. Manimala NJ, Parker J. Evaluation and Treatment of Penile Thrombophlebitis (Mondor's Disease). Curr Urol Rep 2015;16:39.
6. Sasso F, Gulino G, Basar M, Carbone A, Torricelli P, Alcini E. Penile Mondors' disease: an underestimated pathology. Br J Urol 1996;77:729-732.

7. Kumar B, Narang T, Radotra BD, Gupta S. Mondor's disease of penis: a forgotten disease. Sex Transm Infect 2005;81:480-482.

8. Mayor M, Buron I, de Mora JC, Lazaro TE, Hernandez-Cano N, Rubio FA, Casado M. Mondor's disease. Int J Dermatol 2000;39:922-925.

9. Swierzewski SJ, Denil J, Ohl DA. The management of penile Mondor's phlebitis: superficial dorsal penile vein thrombosis. J Urol 1993;150:77-78.

10. Nazir SS, Khan M. Thrombosis of the dorsal vein of the penis (Mondor's Disease): A case report and review of the literature. Indian J Urol 2010;26:431-433.

11. Machan K, Rojo-Carmona LE, Marquez-Moreno AJ, Herrera-Imbroda $B$, Ruiz-Escalante JF, Herrera-Gutierrez D, Acebal-Blanco MM. Ultrasound diagnosis of three cases of Mondor's disease. Arch Esp Urol 2012;65:262266.

12. Boscolo-Berto R, lafrate M, Casarrubea G, Ficarra V. Magnetic resonance angiography findings of penile Mondor's disease. J Magn Reson Imaging 2009;30:407-410. 